in the pursuit of wealth-creation. Only when the recession has ended elsewhere will the British be able to estimate, from the strength of their own recovery, whether British industry can look the rest of the world in the eye.

So is there nothing that Major can learn from Clinton's example? Plenty, as it happens. Last week's speech was a clever blend of carrot (extra spending) and stick (tax increases ahead) whose persuasiveness stemmed from its detail (see page 669). Major cannot use the same recipe because his government cannot risk much extra spending or higher taxes either. But there are other ways in which a convincing message could usefully be put together. Britain, for example, now has more institutions of further and higher education than it has ever had before, and a greater need for skill than ever among the army of the unemployed. Why not subordinate for a time the cry of 'wealth-creation' to what is properly its antecedent, 'skill-creation'? And why not use the forthcoming White Paper on public research as a way of showing, not just saying, that the British government again shares with some of its predecessors the conviction that science and its intelligent application can restore the fortunes of even the most indigent economies?

But would that not just be talk, at best a promise for the future? The British, more pragmatic now than ever, have grown distrustful of promises. Nobody can blame them. But Clinton's message last week was convincing precisely because he acknowledged the seriousness of the problem of the federal deficit, the creation of his two immediate predecessors. If Major and his ministers followed suit, acknowledging that the British economy may still be on its knees when the recession elsewhere is ended, they could well discover that people would listen to them again. The belief that leaders must always express satisfaction with the state of affairs they administer is, as Clinton showed last week, an illusion.

None of that, of course, implies that Clinton is certain to succeed. The rats may get at his policy when it gets to the Congress, while nobody can be sure that he and his advisers have struck the right balance between inflation and deflation. But he deserves high marks for having identified the nature of the problem besetting the United States, and for having courageously set out to solve it. The British problem, although smaller as the numbers read, may be even less tractable. Merely facing up to it will require great daring. The best hope is that a few days in Washington will have persuaded Major that he and his ministers should try to face the downside risks of the fragile British economy - no manufacturing industry except pharmaceuticals and oil production. Then, surely, something would happen.

Meanwhile, the rest of us should not forget that while Britain, the United States and the whole of Western Europe are preoccupied with the prospect of their emergence from recession, the economic goals of just a few years ago that something substantial should be done to rescue Central Europe and parts further east from social as well as economic chaos have been relegated to a distant second place, as have the needs of the poor developing countries. Even Clinton's speech, for all its quality, had little to say on these crucial questions.

\section{Last-chance zoo?}

The London Zoo, in the nick of time, has found a recipe that may help it to survive. Let us hope it works.

IT seems at last as if there may be some light at the end of the tunnel for London Zoo after a hair-raising couple of years on the endangered species list. The zoo's $£ 21$ million plan for a "zoo of the future", unveiled last week, promises a complete financial and structural overhaul of the institution, including the installation of a new "World of Invertebrates" exhibit. Whether or not this includes an enclosure for the zoo's past directors remains to be seen. The zoo's recent troubles, mainly self-inflicted, can be explained only by a unique blend of brashness, timorousness and indifference.

This new-found perspicacity comes not a moment too soon for the ultimate owners, the Zoological Society of London, which the public was beginning to suspect of crying wolf over its financial troubles. Projected closing dates have come and gone with alarming frequency in the past two years, averted by a series of relaunches and rescue bids including a seven-figure donation by the Emir of Kuwait in recognition of Britain's contribution to the Gulf War.

Realizing, perhaps, that military prowess can be a capricious foundation for a zoological organization, the society is sensibly using the Emir's gift as seed money for a sustained but cautious programme of fund-raising and development over the next eight years. If the zoo had shown as much prudence with the $£ 10$ million government grant it received in 1988, its survival might never have been in doubt.

The urban zoo, far from being an imperialist anachronism in these days of animal rights and the wildlife documentary, has a lot to offer the modern world, and should really have little trouble funding itself. The theory and practice of wildlife conservation, for instance, has never before attracted the level of interest and support from the general public that it does today. As people come to recognize the crucial part that zoos have to play in many species' struggle against extinction, the question of whether it can ever be ethical to keep 'wild' animals in captivity has become refreshingly less emotive.

It would also be foolish to overlook the usefulness of zoos to research. As the Human Genome Project progresses and public hysteria over gene therapy starts to abate, an accessible and comprehensive 'animal-library' looks more like a social necessity than an inhumane luxury. Once the importance of keeping animals in captivity has been accepted, the question of whether it is somehow distasteful for people to pay to see them should trouble zoos no longer.

And it is these strengths that London Zoo seems now prepared to cultivate. The new plan is still essentially a fundraising timetable, the likes of which have been seen before, and it will take level-headedness on the part of the directors and better-conceived publicity for its goals to be met on time. But with the focus firmly on conservation and education, and with corporate sponsorship in the offing, the 1990s seem finally to have arrived in Regent's Park. 